\title{
Nutrients and cyclical interdigestive pancreatic enzyme secretion in humans
}

\author{
G Holtmann, D G Kelly, E P DiMagno
}

\begin{abstract}
Background and Aims-It is hypothesised that nutrients increase pancreatic enzyme secretion by converting cyclical interdigestive secretion to a non-cyclical pattern. This study tested the hypotheses that nutrients do not interrupt cycles and determined the relation of nutrients, calories, and osmotic load to the rate of pancreatic secretion.

Methods-Twenty six healthy persons were intubated with oroduodenal and orogastric tubes. Each had one of four different solutions containing 12 to $36 \%$ of calories as protein, 24 to $48 \%$ as fat, and 40 to $64 \%$ as carbohydrate infused into the duodenum at 40,90 , or $160 \mathrm{kcal} / \mathrm{h}$ for 300 minutes. Nine $g / 1$ sodium chloride (290 mOsm) was added to 16 infusates; osmolality of the other 10 infusates was 24 to $98 \mathrm{mOsm}$. Pancreatic enzyme outputs were measured every 15 minutes and peaks of enzyme secretion were identified.
\end{abstract}

Results-The number of enzyme peaks was similar for the different infusates and the proportion of nutrients in the infusates did not affect secretion of individual enzymes. The nadir, but not the peak of the cycles of enzyme outputs correlated with increasing the caloric load $(r=0.55, p<0.003$ for nadir:peak ratio). Increasing osmolality did not affect cycling but reduced $(p<0.001)$ enzyme output.

Conclusion-Nutrients entering the duodenum do not abolish cycles of enzyme secretion; instead they modulate cycles by increasing the nadir. Forty and 90 kcal infusions submaximally stimulate pancreatic secretion and might be used in patients with pancreatitis without producing pain; adding sodium chloride to solutions should increase this effect.

(Gut 1996; 38: 920-924)

Division of

Gastroenterology and Gastroenterology Unit, Mayo Clinic and Mayo Foundation,

Rochester, Minnesota,

USA

G Holtmann

D G Kelly

E P DiMagno

Correspondence to: Dr E P DiMagno, Gastroenterology Research, Mayo Clinic, 200 First Stree SW, Rochester, MN 55905, USA.

Accepted for publication 19 January 1996
Keywords: nutrients, pancreatic enzyme secretion.

Interdigestive (fasting) exocrine pancreatic enzyme secretion consists of cycles that occur every one to two hours. ${ }^{1-3}$ It is commonly believed that in response to nutrients pancreatic enzyme secretion increases and changes abruptly from a cyclic to a non-cyclic pattern. ${ }^{45}$ However, most previous investigators reported the total (mean) output in response to nutrients across subjects. This type of analysis is appropriate to quantify total enzyme secretion but eliminates detecting cycles of enzyme secretion.

It is claimed that enzyme secretion in response to intestinal nutrients is non-specific ${ }^{3}$ (for example, secretion of enzymes is parallel) and that only $10 \%$ of maximal enzyme output is necessary to efficiently digest nutrients. ${ }^{6}$ The duration and magnitude of immediate enzyme secretion in response to nutrients correlate with the physical state (liquid versus solids), ${ }^{78}$ the caloric content, and the type (single nutrient such as essential amino acids versus complex mixtures) ${ }^{4-12}$ of food. The osmotic content of nutrients may also affect the rate of enzyme secretion but hyperosmolar solutions have been reported to inhibit ${ }^{13}$ or stimulate ${ }^{14}$ pancreatic secretion.

Human pancreatic enzyme secretion is affected by the carbohydrate, fat, and protein proportions of the diet eaten for several days or weeks $^{15}$ and possibly different energy loads. ${ }^{16}$ However, there are no data available regarding immediate pancreatic enzyme secretion in response to nutrient mixtures with constant proportions of carbohydrates, fat, and protein but different amounts of calories.

Such data may have clinical importance because increasing pancreatic secretion may cause pain in acute and chronic pancreatitis. In acute pancreatitis, re-feeding may be associated with recurrent pain in the recovery phase. ${ }^{17}$ In chronic pancreatitis inducing proteolytic enzyme dependent negative feedback inhibition of pancreatic secretion by giving trypsin has been associated with decreased pain in some ${ }^{1819}$ but not all ${ }^{20}$ studies. Therefore, determining the relation of caloric, osmolar, and nutrient entry into the duodenum to pancreatic secretion might be important in these clinical situations so that feedings could be given that would minimally stimulate pancreatic secretion.

Thus, we tested the null hypotheses that intraduodenal infusion of nutrients do not interrupt cycles of enzyme secretion. We also determined the pancreatic enzyme response to different caloric and osmotic loads and varying caloric proportions of carbohydrates, fat, and protein.

\section{Methods}

\section{Subjects}

The protocol was reviewed and approved by our Institutional Review Board. After giving informed written consent, 26 healthy persons (11 women, 15 men, age 18 to 56) who had no history of gastrointestinal disease participated in the study. 


\section{Experimental design and infusates}

Each subject was studied once and during the study received a randomly assigned nutrient infusate (Table I). Each nutrient infusate was tested in two or three persons (Table II). For each nutrient infusate, the caloric densities were varied to produce caloric deliveries of 40 , 90 , and $160 \mathrm{kcal} / \mathrm{h}$, while maintaining proportional mixes of nutrients. The infusates contained variable amounts of protein (12 to $36 \%$ of calories, purified casein, Sigma Chemical, MO, USA), fat (24 to $48 \%$ of calories, triolein, Matheson, Coleman and Bell, Norwood Ohio, USA), and carbohydrates ( 40 to $64 \%$ of calories, rice starch, ICN Biochemical, Cleveland, Ohio, USA and limit dextrins and maltotriose, Sigma Chemicals, St Louis, MO, USA). The nutrient solutions had caloric densities of $0.18,0.40$, and 0.71 calories per $\mathrm{ml}$. To control for the possible effects of osmolality, we added sodium chloride $(9 \mathrm{~g} / \mathrm{l})$ to the infusates of 16 experiments to yield an osmolality of 290 mOsm while 10 infusates $(A, B$, and $C$ for all caloric loads and infusate $D$ for $90 \mathrm{kcal} / \mathrm{h}$ ) were prepared without adding sodium chloride yielding osmolalities of 4 to $98 \mathrm{mOsm}$.

\section{Experimental procedure}

On the evening before the study the subjects were admitted to the Clinical Research Center. After eating a standard meal at $600 \mathrm{pm}$, the subjects fasted until the next day when they were intubated with orogastric and an oroduodenal tubes. After verification of tube position by fluoroscopy, saline (154 $\mathrm{mM})$ was infused into the duodenum at a rate of $3.75 \mathrm{ml} / \mathrm{min}$ for 45 to 75 minutes. The saline infusion was then replaced by a nutrient infusion, which was infused at the same rate and continued for 300 minutes. The infusion site was in the descending part of the duodenum and the aspiration site $20 \mathrm{~cm}$ distal. All infusates contained the non-absorbable marker ${ }^{14} \mathrm{C}$ PEG $\left(10 \mu \mathrm{Ci}^{-1}\right)$ so that flow rates could be calculated. ${ }^{21} 22$ After beginning the nutrient infusion, $5 \mathrm{ml}$ duodenal samples were obtained during each 15 minute interval. In 12 randomly selected subjects, saline was infused for 75 minutes before beginning the nutrient infusion. In these subjects, duodenal aspirates were taken during the last 30 minutes of infusion to determine the rate of prestimulatory pancreatic secretion.

Trypsin and chymotrypsin concentrations in the duodenal samples were determined by automatic titration using TAME (tosyl-Lmethyl ester) and ATEE ( $N$-acetyl-L-tryosine ethyl ester) as substrates, respectively, and expressed as units ( $\mu \mathrm{Eq}$ of hydrogen ions

TABLE I Composition and calories provided by carbohydrates, fat, and protein in different infusates

\begin{tabular}{lllll}
\hline & \multirow{4}{*}{$\begin{array}{l}\text { No of } \\
\text { Infusate }\end{array}$} & \multicolumn{2}{l}{ Calories (\%) } \\
\cline { 3 - 5 } & studies & Carbohydrate & Fat & Protein \\
\hline A & 6 & 64 & 24 & 12 \\
B & 6 & 48 & 32 & 20 \\
C & 8 & 40 & 24 & 36 \\
D & 6 & 40 & 48 & 12 \\
\hline
\end{tabular}

TABLE II Number of pancreatic enzyme peaks for each subject during 300 minutes of duodenal nutrient infusion

\begin{tabular}{rllll}
\hline kcal /h & Infusate $A$ & Infusate $B$ & Infusate $C$ & Infusate $D$ \\
\hline 40 & 3,3 & 4,5 & $4,4,5$ & 3,4 \\
90 & 3,4 & 4,4 & $3,3,4$ & 4,4 \\
160 & 3,4 & 4,4 & 3,4 & 4,4 \\
\hline
\end{tabular}

liberated from the substrate per minute per millilitre). Amylase was measured by an automated rate nephelometer (Coleman, Model 91, Amylase-Lipase Analyzer; Coleman Instruments, Oak Brook, IL). In previous studies, we showed that nutrients (casein, triolein, starch) at concentrations up to $34 \mathrm{mg}$ of nutrient per millilitre of duodenal juice did not affect enzyme activities in fresh duodenal juice. $^{23}$

\section{Definitions and data analysis}

Enzyme outputs were calculated for each 15 minute sample by using the measured enzyme concentration and the ratio of the concentrations of ${ }^{14} \mathrm{C}$ PEG in the infusates and duodenal samples. ${ }^{21}$ To evaluate the influence of the nutrient infusions on the pattern of enzyme output, we first determined if peaks of enzyme secretion were present. A peak of enzyme output was defined as a series of four or more values in which at least two consecutive outputs of increasing enzyme value were followed by a lower value or a series of four or more outputs in which the second output was higher than the previous value and was followed by two successive lower outputs. ${ }^{24}$ As all subjects had a minimum of three peaks, we performed the following analyses of the first three peaks in every subject: (1) the outputs during a cycle (defined as the peak output plus the outputs of the 30 minutes before and after an enzyme peak), (2) outputs for each 15 minutes expressed as the per cent of the total per cycle, (3) peak 15 minute output, (4) the nadir (the lowest output), and (5) nadir:peak ratios.

Enzyme outputs were transformed to log values to reduce variance. To examine the relations between peaks and nadirs of cycles, the proportions were transformed to arc sine values to reduce unequal variance at the extremes of proportions.

\section{Statistical analyses}

To test the hypothesis that caloric loads stimulated enzyme output, we used the data from the 12 subjects in whom we had measured enzyme outputs before the nutrient infusion. For this analysis we used an analysis of variance for repeated measures ${ }^{25}$ with body surface as a covariate. In addition, in all study patients, we adjusted enzyme outputs by body weight and used the Spearman correlation to analyse the association between enzyme outputs and caloric loads. Non-parametric methods were used to test the influence of the caloric load and nutrient composition of the infusates on the number of enzyme peaks and the total, minimal, and maximal outputs during cycles. ${ }^{26}$ Spearman rank correlations were used to 


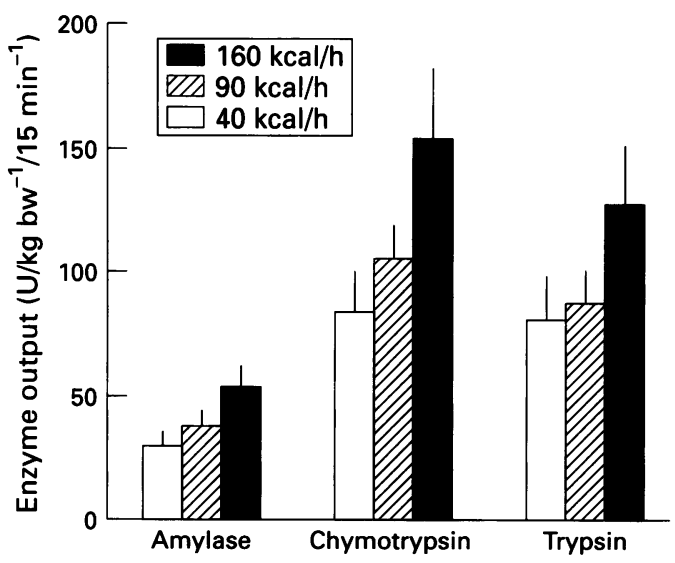

Figure 1: Mean (SEM) total enzyme outputs for the 300 minutes of the study. Outputs of amylase, chymotrypsin, and trypsin were significantly associated with 40,90, and $160 \mathrm{kcalh}$ infused $(\mathrm{r}=0.44, p<0.03, \mathrm{r}=0.44, p<0.03$, and $\mathrm{r}=0 \cdot 32, p<0 \cdot 05$, respectively).

evaluate the association between the caloric loads and the nadir:peak trypsin output ratios. Analysis of variance with Scheffe's test was used to determine if significant differences of enzyme outputs occurred in response to the different caloric loads, nutrient compositions, and osmolalities. ${ }^{27}$

\section{Results}

Enzyme outputs and duodenal nutrient infusions When 40,90 , and $160 \mathrm{kcal} / \mathrm{h}$ were infused, total interdigestive amylase, chymotrypsin, and trypsin outputs increased significantly $(p<0.005)$ in a dose dependent manner during the 300 minutes of intraduodenal nutrient infusions (Fig 1). Outputs of amylase, chymo-

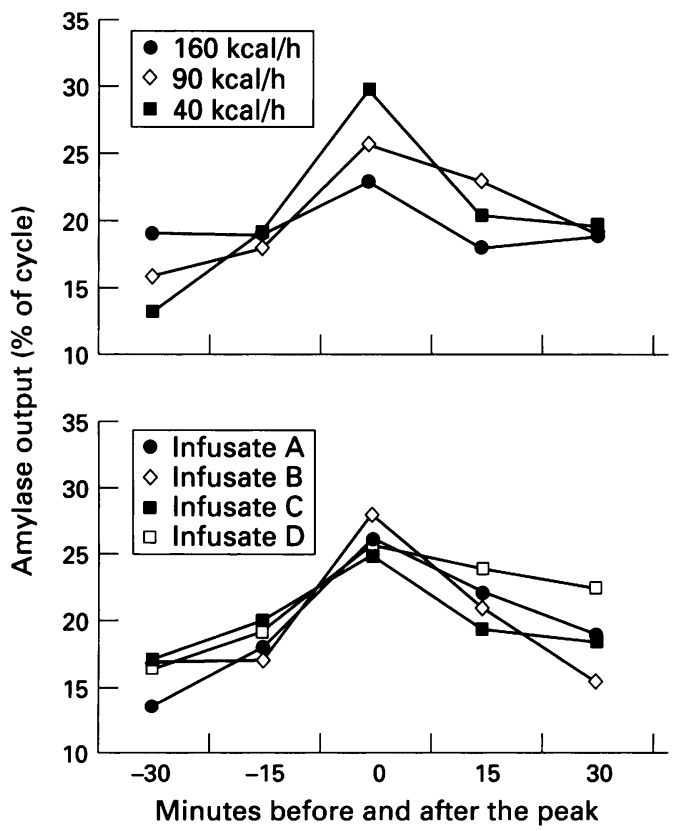

Figure 2: Mean amylase output ( $\%$ of the cycle ${ }^{-15 \mathrm{~min}}$ ) during intraduodenal nutrient infusions. Data are mean values for three cycles observed in each subject for caloric loads (upper panel) of $40(n=9), 90(n=9)$, and 160 $(n=8) \mathrm{kcal}^{-15 \mathrm{~min}}$ and infusates (lower panel) $(A(n=6)$; $B(n=6) ; C(n=8) ;$ and $D(n=6))$. 0 is the time of peak enzyme output.

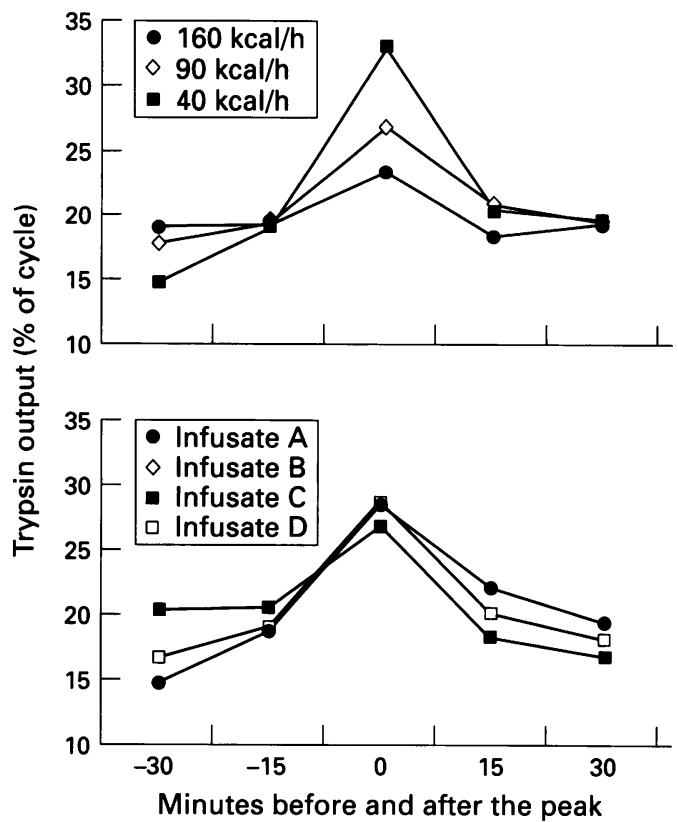

Figure 3: Mean trypsin output (\% of the cycle (15 min) $^{-1}$ during intraduodenal nutrient infusions. Data are mean values for three cycles observed in each subject for caloric loads (upper panel) of $40(n=9), 90(n=9)$, and 160 $(n=8) \mathrm{kcal}^{-15 \mathrm{~min}}$ (lower panel) $(A(n=6) ; B(n=6)$; $C(n=8)$; and $D(n=6)) .0$ is the time of peak enzyme output. Note: On the bottom panel, values for infusates $B$ and $D$ overlap.

trypsin, and trypsin were significantly associated with the caloric load infused $(r=0.44, \mathrm{p}<0.03$, $r=0.44, \mathrm{p}<0.03$, and $r=0.32, \mathrm{p}<0.05$, respectively).

\section{Number of enzyme peaks}

Cycles of pancreatic enzyme output were present during infusion of 40,90, and 160 $\mathrm{kcal} / \mathrm{h}$. Three to five enzyme peaks occurred during nutrient infusions and the number of peaks did not differ among the infusates tested (Table II). As all subjects had at least three enzyme peaks, subsequent analyses focuses on the first three cycles.

Enzyme output during cycles

Enzyme output of amylase (Fig 2), chymotrypsin (data not shown), and trypsin (Fig 3) continued to cycle as the amount of calories infused was increased (upper panels of Figs 2 and 3) and for each of the infusates (lower panels of Figs 2 and 3). Each enzyme output was greater $(p<0.05)$ at the 0 time (peak) compared with the non-peak values for each caloric load and each infusate. However, the nadir values increased significantly as the caloric load increased. Thus, the nadir:peak ratio of the cycles correlated significantly with the caloric loads infused. Figure 4 shows this relation for the sum of the enzyme outputs $(r=0.55, \mathrm{p}<0.003)$.

\section{Effect of proportions of nutrients on cycles}

The proportion of the nutrients in the infusates did not affect the secretion of amylase, chymotrypsin or trypsin outputs (data not shown). 


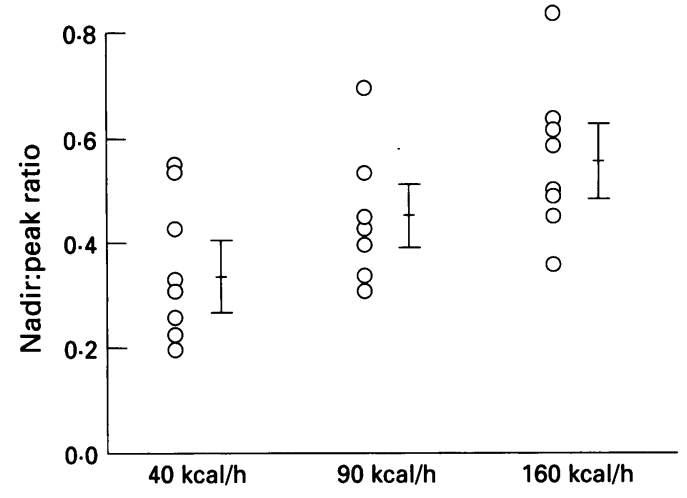

Figure 4: The association of the nadir:peak ratio of total enzyme (amylase + chymotrypsin + trypsin) output and the amount of calories infused into the duodenum. $\mathrm{r}=0.55$; $p<0.003$.

\section{Effect of osmolality}

Osmolality did not affect cycling (Fig 5) but there was a significant $(p<0 \cdot 001)$ inverse relation between enzyme output and osmolality. For example, chymotrypsin, and trypsin outputs (mean (SEM)) were $92(10)$ and 80 (9) $\mathrm{U} / \mathrm{kg} \mathrm{bw} / \mathrm{min}$, respectively, with sodium chloride added to the infusate compared with 142 (26) and 129 (24) U/ $/ \mathrm{kg} \mathrm{bw} / \mathrm{min}$ in response to infusates without sodium chloride.

\section{Discussion}

Our data support the null hypothesis that nutrients entering the duodenum do not abolish cyclical interdigestive enzyme secretion. Instead, nutrients modulate cycles of pancreatic enzyme secretion by increasing the nadir of the cycles in a dose dependent manner. The cycling time (peak to peak time) of pancreatic secretion during intraduodenal nutrients in this study was similar to previous studies of interdigestive secretion we have performed in healthy humans ${ }^{1528}$ during intraduodenal saline infusion. Based on our findings, we hypothesise that the regulatory mechanisms for the cycles of interdigestive secretion continue during the infusion of increasing amounts of nutrients, but that nutrients entrain additional hormonal and neural pathways that gradually increase the nadir of cycles.

Our data agree with studies in rats suggesting that cyclical peaks of exocrine pancreatic

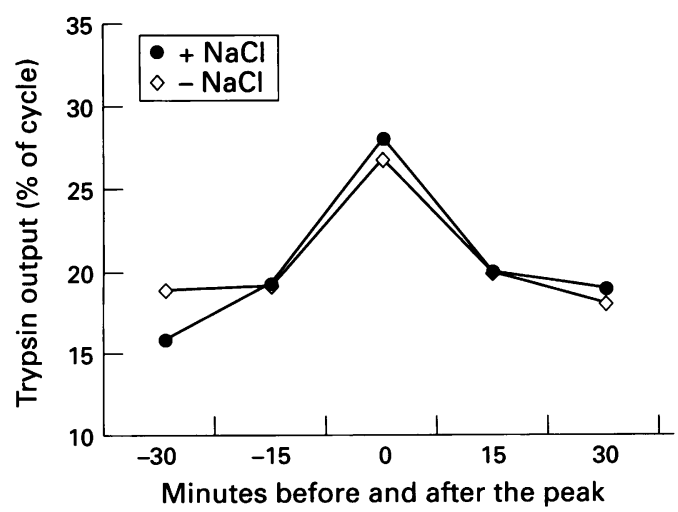

Figure 5: Lack of an effect of osmolality (nutrient infusates with and without sodium chloride ( $\mathrm{NaCl}$ )) on cycling of trypsin. secretion occur during ad libitum feeding. ${ }^{29}$ We, however, seem to contradict data of Katschinski et al ${ }^{30}$ who claimed that infusing $54 \mathrm{kcal}$ per hour of mixed nutrients into the duodenum of humans converted pancreatic interdigestive secretion to a fed pattern but infusion of single nutrients of $21.6 \mathrm{kcal}$ per hour did not. However, their definition of cycles precluded finding modulations of cycles because they arbitrarily decided that 'enzyme outputs exceeding basal levels' represented a fed pattern. Hence, an increase in the nadir of the cycle, regardless of the presence of peaks, were considered a lack of cycling.

The most probable cause of failing to detect cycling in most postprandial studies is that total postprandial enzyme outputs rather than shorter time periods were analysed and averaged across subjects thus eliminating detection of peaks of enzyme secretion. However, it is possible that eating or infusing a meal into the stomach may convert pancreatic enzyme secretion to a fed pattern by activating the gastropancreatic reflex secondary to gastric distension, ${ }^{31} 32$ which is absent with duodenal infusions. Results in rats ${ }^{29}$ suggest that this is not a likely explanation. Acute modulation of interdigestive pancreatic secretion depends mainly on the amount of calories in the infusate and not on the proportions of carbohydrate, fat, and protein.

Because our infusates contained fat, protein, and carbohydrates, we cannot exclude the possibility that equicaloric infusions of a single nutrient class (fat, carbohydrate or protein) modulate interdigestive secretion differently. Although Katschinski et $a l^{28}$ showed that infusates of a single nutrient did not eliminate cycling of enzymes, they infused very little nutrient $(21.6 \mathrm{kcal} / \mathrm{h})$; whether infusion of greater amounts of single nutrients eliminate cycling is unknown. Previously we showed that infusion of single nutrients had different effects on pancreatic secretion. We show in this study that the secretion of enzymes were not affected by proportions of carbohydrate, fat or protein in the infusates, suggesting that the important factor regulating pancreatic enzyme secretion in response to infusion of a mixture of nutrients is the total caloric content rather than the individual nutrients. This effect is accentuated if solutions are hypo-osmolar because adding sodium chloride to the nutrient solutions reduced enzyme secretion. Under chronic conditions, however, nutrient content of diets plays an important part in modulating enzyme secretion. ${ }^{15}$

Osmolality of the infusates did not affect cycling. However, hyperosmolar solutions (those containing $290 \mathrm{mOsm}$ of sodium chloride) decreased enzyme secretion. Our data support previous findings that hyperosmolar solutions inhibit pancreatic secretion ${ }^{13}$ but in Dyck's study the hypertonic solutions increased glucagon values that may have inhibited pancreatic secretion.

Our findings may have clinical implications. The increase in pancreatic enzyme secretion exerted by the caloric loads in our study were modest. For a $70 \mathrm{~kg}$ person trypsin output in 
response to the 40 and $90 \mathrm{kcal}$ infusions were $26000 \mathrm{U}$ per hour, approximately $50 \%$ of maximal output. ${ }^{15}$ Thus, infusing nutrients at this rate into the duodenum submaximally stimulates pancreatic enzyme secretion, provides adequate caloric intake $(2160 \mathrm{cal})$, and might be used to begin to re-feed patients with resolving acute pancreatitis who have recurrent pain. Adding $290 \mathrm{mOsm}$ of sodium chloride to the solutions may even further reduce enzyme secretion. Alternatively, it is reasonable to assume that ingesting small quantities of nutrient solutions at hourly (containing $90 \mathrm{kcal}$ ) or two hourly (containing $180 \mathrm{kcal}$ ) intervals might have the same effect.

It is widespread clinical practice to treat patients in the recovery phase after acute pancreatitis with specific diets containing low proportions of fat and protein. This study of the acute effects of nutrients on enzyme secretion does not negate this rationale but emphasises that total calories are also important in the treatment of such patients.

In summary, we show that infusing increasing amounts of calories into the duodenum increases pancreatic enzyme secretion by raising the nadir of the cycles, but peaks of enzyme secretion continue. Thus, cyclical pancreatic secretion is a feature of both interdigestive and prandial states.

The authors are grateful to Linda J Bakken for secretarial assistance and to Karen J Bentley, Rodney J Sandberg, Laszlo Magosci, and Richard Tucker for skilful technical assistance. Supported by Grant Ho 1193/1-1 from Deutsche Forschungsgemein-schaft, Clinical Research Center Grant RR585, and the Mayo Foundation.

1 DiMagno EP, Hendricks JC, Go VLW, Dozois RR. Relationships among canine fasting pancreatic and biliary secretions, pancreatic ducts pressure and duodenal phase III motor activity - Boldyreff revisited. Dig Dis Sci 1979 24: 689-93.

2 Keane FB, DiMagno EP, Dozois RR, Go VLW Relationship among canine interdigestive pancreatic and biliary flow, duodenal motor activity, plasma polypeptide, and motilin. Gastroenterology 1980; 78: 310-6.

3 Singer MV. Neurohumoral control of pancreatic enzyme secretion in animals. In: Go VLW, Gardner JD, Brooks FP, Lebenthal E, DiMagno EP, Scheele GA, eds. The exocrine pancreas: biology, pathobiology, and diseases. New exocrine pancreas: biology, pathobiology

4 DiMagno EP, Go VLW, Summerskill WHJ. Intraluminal and postabsorptive effect of amino acids on pancreatic and postabsorptive effect of amino acids on pancr

5 Malagelada J-R. Gastric, pancreatic, and biliary response to a meal. In: Johnson LR, Christensen J, Grossman MI, Jacobson ED, Schultz SG, eds. Physiology of the gastrointestinal tract. New York: Raven Press, 1982: 893-924.

6 DiMagno EP, Go VLW, Summerskill WHJ. Relation between pancreatic enzyme outputs and malabsorption in severe pancreatic insufficiency. $N$ Engl f Med 1973; 288: $813-5$

7 Ekelund K, Johannson C. Output of bilirubin and pancreatic enzymes in response to different liquid meals in man. Scand $f$ Gastroenterol 1975; 10: 507-11.

8 Malagelada J-R, Go VLW, Summerskill WHJ. Different gastric, pancreatic, and biliary responses to solid-liquid or homogenized meals. Dig Dis Sci 1979; 24: 101-10.
9 Go VLW, Hofmann AF, Summerskill WHJ. Pancreozymin bioassay in man based on pancreatic enzyme secretion potency of specific amino acids and other digestive products. $\mathcal{F}$ Clin Invest 1979; 49: 1558-64.

10 Malagelada J-R, DiMagno EP, Summerskill WHJ, Go VLW. Regulation of pancreatic and gallbladder function by intraluminal fatty acids and bile acids in man. 7 Clin Invest 1976; 58: 493-9.

11 Malagelada J-R, Go VLW, DiMagno EP, Summerskill WHJ. Interactions between intraluminal bile acids and digestive products on pancreatic and gallbladder function. digestive products on pancreatic ar

12 Fried M, Jansen JB, Harpole T, Taylor IL, Lamers CB, Reedy $\mathrm{T}$, et al. Pancreaticobiliary responses to an intragastric amino acid meal: comparison to albumin, dextrose, and a maximal cholecystokinin stimulus. Gastroenterology 1989; 97: 1544-9.

13 Dyck WP. Influence of intrajejunal glucose on pancreatic exocrine function in man. Gastroenterology 1971; 60 864-9.

14 Dooley CP, Valenzuela JE. Duodenal volume and osmoreceptors in the stimulation of human pancreatic secretion. Gastroenterology 1984; 86: 23-7.

15 Boivin M, Lanspa SJ, Zinsmeister AR, Go VLW, DiMagno EP. Are diets associated with different rates of human EP. Are diets associated with different rates of human interdigestive and postprandial pancreatic
tion? Gastroenterology 1990; 99: 1763-71.

16 Emde C, Lierh RM, Gregor M, Pleul O, Riecken ED, Menge $\mathrm{H}$. Lack of adaptive changes in human pancreatic amylase and lipase secretion in response to a high carbohydrate, low-fat diet applied by a 10 day continuous intraduodenal infusion. Dig Dis Sci 1985; 30: 204-10.

17 Banks PA. Medical management of acute pancreatitis. In: Go VLW, DiMagno EP, Gardner JD, Lebenthal E, Reber HA, Scheele GA, eds. The pancreas. Biology, pathobiology, and disease. 2nd ed. New York: Raven Press, 1993: 593-611.

18 Slaff J, Jacobson D, Tillman CR, Curington C, Toskes P. Protease specific suppression of pancreatic exocrine secreProtease specific suppression of pancre
tion. Gastroenterology 1986; 87: 44-52.

19 Isaksson F, Ihse I. Pain reduction by an oral pancreatic enzyme preparation in chronic pancreatitis. Dig Dis $S c$ 1983; 28: 97-102.

20 Mössner J, Secknus R, Meyer J, Niederau C, Adler G Treatment of pain with pancreatic extracts in chronic pancreatitis. Gastroenterology 1991; 100: A290.

21 Go VLW, Hofmann AF, Summerskill WHJ. Simultaneous measurements of total pancreatic, biliary, and gastric outputs in man using a perfusion technique. Gastroenterology 1970; 58: 321-8.

22 Wingate D, Sandberg RJ, Phillips SF. A comparison of stable and $14 \mathrm{C}$ labelled polyethylene glycol as volume indicators in the human jejunum. Gut 1972; 13: 812-5.

23 Kelly DG, Sternby B, DiMagno EP. How to protect human pancreatic enzyme activity in frozen duodenal samples. pancreatic enzyme activity in frozen

24 Malfertheiner P, Sarr MG, Spencer MP, DiMagno EP. Effect of duodenectomy on interdigestive pancreatic secretion, gastrointestinal motility, and hormones in dogs. Am f Physiol 1989; 257: G415-22.

25 SAS Institute Inc. SAS/STAT User's Guide. Release 6.03, Edition, Cary, NC: SAS Institute Inc, 1988

26 Winer BJ. Statistical principles in experimental design. 2nd ed. New York: McGraw-Hill, 1971.

27 Scheffe $\mathbf{H}$. A method of judging all contrasts in the analysis of variance. Biometrika 1953; 40: 87-104.

28 Keane FB, DiMagno EP, Malagelada J-R. Duodenogastric reflux in humans: relationship to fasting antroduodenal motility and gastric, pancreatic, and biliary secretion. motility and gastric, pancreatic,

29 Maouyo D, Sarfati P, Guan D, Morisset J, Adelson JW. Circadian rhythm of exocrine pancreatic secretion in rats major and minor cycles. Am f Physiol 1993; 264 G792-800.

30 Katschinski M, Dippel C, Reinshagen M, Schirra J, Arnold R, Nustede R, et al. Induction of the fed patter of human exocrine pancreatic secretion by nutrients: role of cholecystokinin and neurotensin. Clin Invest 1992; 70 902-8.

31 White TT, Lundgh G, Magee MF. Evidence for the existence of gastropancreatic reflexes. Am f Physiol 1960; 198: 725-8.

32 Vantrappen GR, Peeters TL, Janssens J. The secretory component of the interdigestive migrating complex in man ponent of the interdigestive migrating 